\title{
NE YAKIN NE UZAK BİR TARİHSEL HADİSE: İBRAHIMM HALİL SOĞUKOĞLU VE KÜRTDAĞI MÜRITT HAREKETİ
}

\section{Sever IŞIK*}

\section{$\ddot{O} \mathbf{z}$}

Halep'in kuzeyinde Kürtdağı (Cebeliekrad) bölgesinde Nakşi şeyhi Halil İbrahim Soğukoğlu'nun çevresinde oluşan Mürit Hareketi yakın tarihimizin önemli fakat ihmal edilmiş olaylarındandır. Bu makalenin amacı bu hareketin tarihsel gelişim seyrini ortaya koymak ve harekete dair bazı çıkarımlarda bulunmaktır. 1920'li yılların sonlarından itibaren oluşan Mürit Hareketi zamanla sosyal ve anti-feodal bir karakter edinmiştir. Türkiye ile derin bağlantıları olan hareketin başındaki isim olan Soğukoğlu, bölgede kendisini asker olarak tanıtmıştır. Hem Türkiye'nin hem de Suriye'deki Vatan Kitlesi'nin Fransız karşıtı karakterinden dolayı desteklediği hareket, özellikle 1936'dan itibaren güçlenmiş ve bölgede bir güç odağı haline gelmiştir. Müritler önce Fransızları destekleyen ağalarla daha sonra ise Fransızlarla çatışmışlardır. Sonunda Fransızlar Kürtdağı'ndaki harekete karşı uçakları ile katıldıkları bir askerî harekât düzenlemişlerdir. Harekât sonunda çok sayıda kişi Türkiye'ye iltica etmiş ve burada iskân edilmişlerdir. Hatay'ın Türkiye'ye katılmasında rol oynayan hareket, özellikle hareketin bileşenlerinin kimlikleri ve resmi politik söylemin çerçevesine uymaması sebebiyle görmezden gelinmiştir. Aynı zamanda sistematik ve organize olmamakla beraber hareket, Türkiye'nin en azından bir siyasal manevra olarak zaman zaman Halep'i ve kuzeyini almak gibi bir politik niyeti sergilediğini ortaya koyması bakımından önemlidir.

Anahtar Kelimeler: Halil İbrahim Soğukoğlu, Mürit Hareketi, Kürtdağı, Hatay, Halep

\section{NEITHER NEAR NOR FAR A HISTORICAL EVENT: İBRAHIM HALIL SOĞUKOĞLU AND THE KURD-DAGH MOURIDE MOVEMENT}

\begin{abstract}
The movement of the Murid formed around Naqshi Sheikh Halil İbrahim Soğukoğlu in the region of Kurd-Dagh in the north of Aleppo is an important but neglected event of our recent history. The aim of this article is to examine historical development of the movement and is to make some inferences about the movement. The Murit movement, which has been formed since the end of the 1920's, gradually became a social and anti-feudal character. Soğukoğlu, who has connections with Turkey, introduced himself as a soldier in the region. The
\end{abstract}

Makale Gönderim Tarihi: 14.12.2017, Kabul Tarihi: 01.08.2018

Doi: $10.26791 /$ sarkiat.365699

*Dr. Öğr. Üye. Gaziantep Üniversitesi, Fen-Edebiyat Fakültesi, severquista@gmail.com, Orcid ID: https://orcid.org/0000-0002-8401-2353 
movement was supported both by Turkey and by the Patriotic Masses in Syria due to its anti-French character which has been strengthened since 1936 and has become a powerhouse in the region. The murids first clashed with the French supported local big landowners, then with the French army. Finally, the French occupation organized a military campaign involving aircrafts against the movement on the Kurd-Dagh. At the end of the campaign, a large number of people fled to Turkey and settled there. The act that played a part in the participation of Hatay in Turkey was ignored especially because the components of the movement did not fit the frame of the identity and official political discourse. At the same time, the movement is not systematic and organized but it is important for Turkey to demonstrate that it at least showed political intention to take the Aleppo and its northern region from time to time as a political manoeuvere.

Keywords: Halil İbrahim Soğukoğlu, Mouride Movement, Kurd-Dagh, Aleppo, Hatay

\section{Giriş}

Mürit Hareketi ya da "Müridizm" İslam dünyasında Nakşi şeyhi Şeyh Şamil öncülügünnde 19. yüzyılda Kafkasya'da Çarlık Rusyası'na karşı girişilen uzun süreli direniş hareketine verilen addır ve adeta onunla özdeşleşmiştir. Bizim burada konu edineceğimiz Mürit Hareketi Kuzey Suriye'de, Kürt Dağı'nda (Kürtçe adı: Çîyaye Kurménc, Arapça adı: Cebeli Ekrad) ortaya çıkan, yakın tarih literatüründe kendisine pek yer bulamayan bir kişilik olan Halil İbrahim Soğukoğlu'nun oluşumuna öncülük ettiği önemli bir harekettir. Suriye'nin Fransa karşıtı mücadelesine ve Hatay'ın Türkiye katılmasına katkıda bulunan söz konusu hareket Türk, Arap ve hatta Kürt ulusal tarih anlatıları tarafından görmezden gelinmiştir. Nakşi şeyhi İbrahim Halil Efendi etrafında gelişen söz konusu dinsel uyanış hareketi önce ağalık bir süre sonra da Fransız karşıtı bir karakter edindi. Sosyal bir karakter taşıyan, halkta taban bulan hareketin sonraki gelişim seyri ve diğer hareketlerle etkileşimi ilginç veriler sunma potansiyeli içermekle beraber bu konuda elde yeterince veri ve yapılmış saha araştırması yoktur. Şeyhin mobilize ettiği çoğu Kürt müritler önce Fransız manda yönetiminin desteklediği yöredeki ağalar ile bir süre sonra ise Fransızlarla karşı karşıya geldiler ve bu karşılaşma 1935-36 sonrasında çatışmaya dönüştü. Kürt Dağı'nın sosyal ve siyasal yaşamında önemli rol oynayan hareket Fransızlar tarafindan "Mouvement Mouroud" (Mürit Hareketi) olarak isimlendirildi. Mürit Hareketi hakkındaki tek kısa monografik çalışmanın Le Kurd Dagh et le mouvement Mouroud'in (Kürt Dağı'nda Mürit Hareketi) yazarı Roger Lescot'a göre Kürt Dağı'ndaki Mürit Hareketi ile Kafkasya'daki Mürit Hareketi arasında bir ilişki olmamakla beraber aralarında benzerlikler vardır (Lescot, 1993:3). Müritleriyle birlikte Ruslara karş1 savaşan Sünniliğe dayanan eşitlikçi bir devlet kurmayı amaçlayan Şeyh Şamil Vehhabilerin tesiriyle kahve ve tütün içimini yasaklamıştı. İbrahim Halil'in mürit hareketi de itikadi olarak tamamen Sünni bir yapıya sahipti. Din dışı müziği yasaklayan şeyh, tütün kullanımına da karşı çıkmış ve müritlerine peygamber gibi kısa sakal bırakmalarını salık vermiştir (Lescot, 1993:31-32). Faaliyet gösterdiği Kürt Dağı bölgesiyle önemli ölçüde bütünleşen İbrahim Halil Efendi, bölgeden 
evlilikler yapmış, zamanla şiir yazacak kadar Kürtçe öğrenmiştir ki Kenz-i Şümûs ${ }^{1}$ isimli şiir divanında ve divanının dışında da Kürtçe şiirleri bulunmaktadır. Şeyh, hayatının sonuna kadar Kürt Dağı'ndaki müritleriyle ilişkisini de devam ettirmiştir. Ayrıca Şeyhin 1930'ların ikinci yarısından sonra Türkiye ve Suriye'deki Vatan Kitlesi (el-Kitle el-Vataniyye) önemli ilişkiler geliştirdiğini belirtmek gerekir. Şeyhin niteliği ve yoğunluğu tam olarak ortaya konul/a/mayan derin ilişkileri hareketin üzerinde bir sis perdesi olarak durmaya devam etmektedir.

Kürt Dağı'nın Türkiye'ye katılımını amaçlamasına, Hatay'ın Türkiye'ye katılımına ve Suriye'nin Fransa'ya karşı mücadelesine katkısına rağmen Türkiye'de ve özellikle Baas iktidarı sonrası Suriye'de milliyetçi tarih yazımları Mürit Hareketi hakkında sessiz kalmışlardır. Hatay Meselesi'nde aktif olan ve daha sonra hatıralarını kaleme kişilerde Halil İbrahim Efendi'den ve Mürit Hareketi'nden bahsetmemişlerdir. Bu tutumun birçok sebebi olabilir. Söz konusu tarih yazımlarının Kürtlerin ismini taşıyan bir bölgede yaygınlık kazanmış dini ve sosyal karaktere sahip bir hareketin başarılarını kendilerine dönük bir katkı olsa da ulusal tarih anlatısına dahil etmek istemedikleri, hareketin bileşenlerinde kendisinden kurtulmak ya da görünmez k1lmak istedikleri (din, etnisite vb.) unsurlar ve çehreler buldukları düşünülebilir. Yine Cumhuriyetin politik söylemine ve pratiğine ters düşmesi ve politik pragmatizmini göstermesi sebebiyle de Türkiye'nin İbrahim Halil Efendi ile ilişkisi görünmezden gelinmiş olabilir. Zira içeride tasfiye edilmek istenen şey dışarıda teşvik edilmiştir.

$\mathrm{Bu}$ makalenin amacı yakın tarihin ihmal edilmiş dolayısıyla bilinçlerimize uzak kalmış bu hareketinin tarihsel gelişimini incelemek ve bunun akabinde harekete dair bazı çıkarımlarda bulunarak onu tarihsel olarak konumlandırmak ve anlamlandırmaktır. Bu kısa girişten sonra İbrahim Halil Efendi'nin biyografisine ve hareketin daha ayrıntılı gelişimine bakabiliriz.

\section{1. İbrahim Halil Soğukoğlu ve 1929-1935 Dönemi Mürit Hareketi}

Hareketin merkezindeki sima olan İbrahim Halil Soğukoğlu, Artvin'den İzmit'e gelip yerleşen Gürcü kökenli ${ }^{2}$ bir ailenin çocuğu olarak 1901'de (Hicrî 1319, Rumi 1317) İzmit'in Gölcük kazasının Hamidiye köyünde doğdu. ${ }^{3} 13-14$ yaşına kadar babasının yanında klasik medrese usulü ile İslami ilimler tahsil etti. Gençlik dönemi tasavvufî eğitimle geçen İbrahim Halil Efendi eğitim süresi içerisinde Suriye, Mısır, Irak, Arabistan ve Yunanistan'a yolculuk yaptı. Birçok mürşidi oldu. Seyr u sülûk müddeti içinde yanında en uzun kaldığı mürşidi

\footnotetext{
${ }^{1}$ Söz konusu divana dair bir tanıtım yazısı için bkz. Kenan Erdoğan, Tuğba Aydoğan, "Manisa'da Medfun Mutasavvıf Bir Şair: Seyyid İbrahim Halil Efendi ve Divanı Kenz-i Şumus”, Celal Bayar Üniversitesi Sosyal Bilimler Dergisi, Cilt:11, S. 3, 2013.

${ }^{2}$ Şeyhin kendi ifadelerine istinaden baba tarafından nesebinin Hz. Hüseyin'e ulaştığını ifade eden Fehmi Soğukoğlu'a göre şeyhin dedeleri Kafkaslardan gelip Artvin'e yerleşmiş ve burada "Gürcüleşmiş”lerdir. Bkz. Fehmi Soğukoğlu, “İbrahim Halil Efendi ve Mürit Hareketi’nin Millî Mücadele’ye Katkısı”, Millî Mücadele’de Güney Bölgesi Sempozyumu” içinde, Atatürk Araştırma Merkezi Yayınları, Ankara, 2015, s. 244. 1937 tarihli resmi devlet evrakında kendisinden "Çoruh vilayetine bağlı Arhavi Nahiyesi halkından" şeklinde bahsedilmektedir. Bkz. Başbakanlık Cumhuriyet Arşivi, Kararname, 19.7. 1934, 1058; Kararname, 3.2.937, 5986.

3 Roger Lescot, Soğukoğlu'nun doğum tarihini 1897 olarak vermektedir. Bkz. Lescot, a.g.e., s. 28; Ayrica bkz. D. Muhammed Abdu, 2007
} 
Humuslu Şeyh Ebü'n-Nasr Halef'dir (Soğukoğlu, 1987: 10-11; Soğukoğlu, 2011:7-11). ${ }^{4} 1925$ yılı civarında Suriye'ye giden İbrahim Halil Efendi birçok şeyhten ders ve icazetname aldı. Daha sonra bir süre İslahiye'ye yerleşerek faaliyet gösterdi ve etrafında bazı müritler topladı. Fakat devletin tazyiki sebebiyle yeniden Suriye’ye dönmek zorunda kald1 (Lescot, 1993:28: Abdo, 2007).

Şeyh Said İsyanı'nı müteakip ihtiyat askeri olarak askere alınan İbrahim Halil Efendi 1928 yılında askeri bir emirle istihbarat takibi için Suriye gönderildi. Burada kalan ve birliğine dönmeyen şeyh, terhis edildi. Mürşitlerinden Ebü'nNasr Halef'nin yanında bir süre eğitim gören şeyh, Şam, Lübnan ve Ürdün'e gitti. Buralarda ilim ehli kimseleri ziyaret ederek onlarla Suriye ve İslam dünyasının o zamanki durumunu müzakere etti (Soğukoğlu, 2011:13). 1929'da Suriye'nin kuzeyine, ağırlıklı olarak Kürtlerin yaşadığı Halep'in'in Afrin bölgesine yerleşti. İbrahim Halil Efendi'nin Suriye'ye gönderilmesine sebep olan istihbari görevin ne olduğu, dönmemesine rağmen niçin terhis edildiği ${ }^{5}$ aydınlatılmayı bekleyen sorular olarak ortada durmaktadir.

Afrin'de, Şeyh Horoz (Şêx Oroz) köyüne yerleşen ve Uryâ Nebî (Hûri Nebî) Cami'yi tamir ederek burada vaaz ve nasihatte bulunmaya başlayan Halil Efendi kısa zamanda bölge halkından çok sayıda mürit edindi. Keramet gösterdiği rivayet olunan şeyhin şöhreti kısa sürede civar köylere yayıldı. Bölgeye gelen bir yabancı olarak şeyhin büyük bir nüfuz kazanması ve aşağıda bahsedeceğimiz faaliyetleri bölgedeki bazı ağaları rahatsız etti. Önceleri şeyhe sahip çıkan Şeyh İsmailzade ailesi de bir süre sonra faaliyetleri sebebiyle ondan uzaklaştı (Soğukoğlu,2011:15; Lescot, 1993:28-29; Soğukoğlu, 1987: 20; Öztürk, 1995:18). Soğukoğlu bunu şeyhin bölgede ilim seferberliği başlatmasının, halktan bir çoğunun okur yazar haline gelmesinin, dini ilimlere vakıf olmasının yarattığı sosyal değişim neticesinde köylülerin ağaların kontrolünden çıkmasına bağlar (Soğukoğlu, 2011:15). Fakr û zaruret içindeki halkı ağalara karşı bilinçlendiren Şeyh, kısa süre sonra yöre halkı üzerinde hukuki ve iktisadi baskı kuran ve Fransızların desteklediği ağalarla karşı karşıya geldi ve kendisine kesin bir itaatle bağlı olan müritleri ağalara karşı mobilize ederek onlara karşı direnmeyi telkin etti (Öztürk, 1995: 18, 2005:28; Fuccaro, 2004: 593, Çelebioğlu, Mülakat 2016). ${ }^{6}$ Hareket zamanla sosyal bir karakter edindi ve sayısı artan müritler bir güç odağı haline gelmeye başladılar.

Kürt Dağı'ndaki Kürt toplumunun sosyolojik yapısı göz önüne alındığında İbrahim Halil Efendi'nin etrafında kısa sürede böyle bir yapılanmanın

\footnotetext{
${ }^{4}$ R. Lescot ile birlikte sık sık başvurduğumuz Fehmi Soğukolu'nun bilgi kaynaklarını bilmek okuyucunun bilgileri daha iyi değerlendirmesine katk1 sağlayabilir. Soğukoğlu'nun en önemli kaynakları İbrahim Halil Efendi'nin yayınlanmamış Not Defteri ile İbrahim Halil Efendi'nin ölümünden sonra müritlere liderlik eden Nahsan Efendi'nin yazdığ İbrahim Halil Efendi Kimdir? isimli yayınlanmamış biyografi ve aile efradı ile yapılan mülakatlardır. Türkçede harekete ilişkin tek makale ise Mustafa Öztürk'ün 1938 Suriye Olaylarl ve İbrahim Halil Efendi'nin Faaliyetleri isimli sözlü kaynaklara dayanan kısa makalesidir.

${ }^{5}$ F. Soğukoğlu daha sonra sunduğu bir tebliğde bu görevin "Suriye'ye kaçmış bir suçlu hakkında bilgi alıp güvenlik güçlerine bildirmek" olduğunu ifade eder. Şeyh Arapça bildiği ve Suriye'yi tanıdığı için bu göreve seçilmişti, görevli olarak gittiğinden ve belirtilen süre içinde dönemediğinden terhis edilmişti (Soğukoğlu, 2015:245).

${ }^{6}$ Şükrü Çelebioğlu, 1928 yılı Kilis ili Süngütepe köyü doğumludur. Şu anda Gaziantep’te ikamet etmektedir.
} 
oluşmasında onun karizmatik bir kişilik oluşu ve halk tarafından "keramet sahibi" olarak görülmesi önemli rol oynamış görünse de şeyhin kısa sürede büyük nüfuz kazanmış olması başka sebeplerle de izaha muhtaç bir durumdur. Hareket sosyal karakteri itibarıyla ağalık karşıtı bir görünüm arz etmektedir. Fakat bunun Soğukoğlu'nun sosyo-teolojik görüsslerinin mi yoksa politik amaçları tarafından mı domine edildiğinin daha iyi aydınlatılması gerekir. Dönemin iktisadi koşulları ve sosyolojinin şeyhin faaliyetini kolaylaştırdığı, hareketin kısa sürede kök salması için uygun olduğu açıktır. Lescot'a göre Mürit hareketinin başarısı dini fanatizminden değil, sosyal yapısından kaynaklanmaktaydı. Güçlü ağa ve büyük ailelerin sıradan halk-köylü üzerindeki egemen konumu, yöneticilerle ilişkileri, köylüyü borçlandırması, arazisine el koyması vb. olgular hareketin sosyal zeminini oluşturmuştur. Bununla birlikte söz konusu dönemde bölgede yaygın Kürt milliyetçi faaliyetinin olmaması sebebiyle dışarıdan (Türklerden, Araplardan ya da Fransızlardan) gelen siyasi faaliyetlere ve yönlendirmelerine açık olması da bölgeyi, bölgenin siyasi ve sosyal yapısında önemli bir rol oynayacak olan Mürit Hareketi'ne hazır hale getirmiştir (Lescot, 1993:23-25). Thomas Bois de Mürit İsyanı'nı Kürt köylülerin kötü yaşam koşullarına bağlar (Bois, 2004: 143). Söz konusu dönemde bölgenin politik vaziyeti de ekonomik ve sosyal yapısıyla doğrudan ilişkili olmuştur. Suriye'nin Kürtlerle meskun diğer bölgelerinde olduğu gibi sosyo-ekonomik yapı Kürt Dağı'nında da siyasetin elitler tarafından icra edildiği; aşiret, aile, vb. kolektif aidiyetlerin bireysel aidiyetin önünde geçtiği primordialist politik ilişkilerin devamını mümkün kılmıştır (Tejel, 2009:13). Genel olarak ekonomik durumun kötü, nüfusun çoğunluğunun kırsalda meskun ve tarımla meşgul olduğu Kürt Dağı'nda ekonomik, sosyal ve politik alan büyük toprak sahibi ağalar tarafından kontrol edilmekteydi. Küçük toprak sahipleri ve topraksız köylüler ekonomik olduğu kadar politik patronaj itibarıyla da ağalara bağ(1m)lıydılar (Lange, 2010:411). Böyle bir ortamda hareket çoğunlukla toprakları elinden alınan fakir kesimler, ağaların denetiminden çıkan küçük toprak sahibi köylülerce desteklendi. Müritlerin köylülerin söz konusu şikayet ve sosyal taleplerini ağalara karşı kullanması zamanla kendilerini destekleyen ağalarla aralarının açılmasıyla sonuçlandı. Büyük aileler hareketin büyümesine karşı çıktılar (Lescot, 1993:32-34: Fuccaro, 2004:593). Bu ilk dönemlerinde bölgenin sosyal yapısıyla etkileşim içinde doğal bir gelişim gösteren hareketin ağalık karşıtı halkçı, eşitlikçi bir karakter sergilediği görülmektedir.

Müritlerin etrafında toplandığı şeyh, ağalar tarafından Türk istihbaratından olduğu, Türkiye tarafından özel olarak gönderildiği gerekçesiyle Fransız yetkililere diğer taraftan da şeyhin "Türkiye aleyhinde olmakla suçlayıp, Türkiye' de yasak olan şeyhlik ve tarikat faaliyetlerinde bulunduğunu" söyleyerek Türk makamlarına, Kilis’teki Halk Fırkası başkanı İsmail Bey’e da şikayet ettiler. Soğukoğlu bunu şeyhten kurtulmak isteyenlerin bir suçlaması/iftirası olarak aktarır. Fakat şeyhin zaman zaman bazı devlet görevlileri ile görüştüğünü de ifade etmekten geri kalmaz (Soğukoğlu, 2011:16). Gerçekte sınırın Türkiye tarafındaki yerel halk da şeyhin Atatürk tarafından gönderildiğini söylemekte ve buna inanmaktadır (Öztürk, 1995:18; Çelebioğlu, Mülakat 2016). Sonuçta Fransızlar tarafindan tutuklanarak 1930 Temmuzunda Kilis'ten Türkiye'ye teslim edilen şeyh, Gaziantep'e sevk edildi. Soğukoğlu'na göre Suriye'den gelen raporlar 
sebebiyle şapka aleyhine halkı tahrik suçlamasıyla hapishaneye atıldı. ${ }^{7}$ Gaziantep cezaevinde 16 ay kalan şeyh burada birçok dost edindi (Soğukoğlu, 2011: 17). 1931 'de cezaevinden salıverilen şeyh, Antep'te ikamet etmek istese de emniyetin baskısı ile İzmit'e döndü. "Göstermelik bir marangoz açarak halkın arasına karışan" (Soğukoğlu, 2011:16) şeyh burada birçok devlet yetkilisiyle iyi diyaloglar kurar ve bir süre sonra Gaziantep'e döner. Gaziantep'te yeni müritler edinen şeyh Suriye' deki müritleri ile de yeniden ilişki kurar. Bu arada yaptığı tüm faaliyetleri emniyetçe takip edilmekte olan İbrahim Halil Efendi'nin 'birkaç kez Ankara'ya da giderek dönemin hızlı gelişen siyasetine yön verme çabası içerisinde olduğu görülmektedir" (Soğukoğlu, 2011:18-19). Aynı yıllarda müritler de Vatan Kitlesi ile ilişki kurmuşlardır. Suriye'deki faaliyetlerini Gaziantep'ten yürüten şeyh, 1934 yılında Bakanlar Kurulu kararıyla Bilecik'te mecburi iskana tabi tutuldu (Bkz. Başbakanlık Cumhuriyet Arşivi, Kararname, 3.2.937, 5986). ${ }^{8}$ Fakat şeyh burada da müritleriyle ilişkilerini ve iletişimini devam ettirir (Soğukoğlu, 2011: 18-19). Gerçekte dönemin koşulları düşünüldüğünde şeyhin müritleriyle ilişkisinin sürekliliğini nasıl koruyabildiği düşündürücüdür. Ayrıca şeyhin Ankara' da kimlerle görüştügü̈, arzusuyla mı yoksa çağrı üzerine mi gittiği hususunda açık bir bilgi mevcut değildir. Bununla beraber şeyhin Ankara'ya gittiğine dair mevcut bilgi, şeyh ve bazı devlet yetkileri/organları arasındaki ilişkinin erken bir tarihte başlamış olabileceği kanaatini güçlendirmektedir.

Şeyhin Türkiye'de olduğu dönemde müritlerin başlarına Hanif Arabû Efendi’yi (ö. 1947) ve Ali Galib'i (Eli Xaleb) vekil olarak bırakmış, Şeyh Hanif hareketin dini liderliğini yaparken Ali Galip ise maddi mesuliyetini yüklenmiştir (Lescot, 1993:44, 28-29). Şeyhin Türkiye'de olduğu bu süreç içinde Müritler Fransızlar ile silahlı çatışmaya devam eder. Soğukoğlu'na göre hareketin amacı Suriye'nin bağımsızlığıdır (Soğukoğlu, 2011:19). Gerçekte şeyh Suriye'den ayrılırken halifesi Hanif Arabo'ya kendi mürşitlerinden Ebu Nasır ile istişare etmesini salık vermiştir ki söz konusu bu kişiler de Suriye milli mücadelesini desteklemektedirler.

\section{1935/6-1939 Dönemi Mürit Hareketi}

Hareketin önemli simalarından silahlı grubun reisi Reşid İbo'nun desteğine rağmen hareketin 1935 'e kadar fazla gücü yoktur. Bu tarihten sonra ise Halil İbrahim'in Türkler, Ali Galib'in ise Vatan Kitle'si ile geliştirdiği ilişkiler sayesinde hareket daha da güçlendi (Lescot, 1993:45, 38-39). Ali Galip 200-300 kişi ile birlikte Doğu Ekspres'i ile Fransa'dan dönen Suriye Wefdlilerini karşılayarak Suriye Milli Mücadelesi'ni destekleme sözü verdi. Buna karşılık Suriye yöneticileri de müritleri lojistik olarak desteklediler ve faaliyetlerine göz yumdular. 1936'da, Halep'teki Suriye milliyetçileri ile Kemalistler Fransızların bölgedeki konumunu zayıflatmak umuduyla hareketi desteklemeye başladılar (Lescot, 1993:45, 38-39). Çünkü müritler Fransa'ya karşı onların elleri

\footnotetext{
7 Reşid Hamo'nun konuya dair Sewretü Cebeli'l-Ekrad:Harekeü'l Müridin (Kürt Dağı Devrimi: Mürit Hareketi) isimli çalışmasının sonuna eklediği bir fotoğraftan Şeyh'in, muhtemelen bundan sonraki tarihte şapka giydiğini öğreniyoruz.

${ }^{8}$ Lescot'a göre şeyh Bilecik’te iken bölgede (İslahiye-Kilis) kendisine düşman olan Komiser Niyazi Uz Alp, 1930'da şeyhin İslahiye'de tarikat faaliyeti yürüttüğüne ve bazı öldürme olaylarına karıştığına dair bir rapor hazırladı. Bunun üzerine yargılanan İbrahim Halil Efendi, Emniyet Genel Müdürlügü sayesinde aklandı (Lescot, 1993:44).
} 
güçlendirmekte idi. 1936 seçimlerinde bölgede Kör Reşid'e' karşı müritlerin desteklediği Hüseyin Avni'nin ${ }^{10}$ seçimi kazanması ile Mürit Hareketi gücünün farkına vardı. Aynı süreçte hareketin düşmanları da artı. Reşid İbo'nun başında bulunduğu hareketin milisleri/çeteleri bölgeyi kontrolüne alırken, ağaların arasındaki kavgalar eksik olmuyordu (Lescot, 1993: 45). Tahmini olarak 19351936 yıllarından itibaren ağalara ve taraftarlarına karşı müritler vasıtasıyla suikastlar düzenledi. Ağaların, dolayısıyla da Fransızların bölgedeki otoritesi zayıfladı (Öztürk, 2005). 1937'ye gelindiğinde durum tam olarak değişmediyse de Şeyh Hanif, Reşid İbo, Ali Galip'in tutuklanması ile hareket biraz zayıfladı, fakat tutuklular Nisan 1938'de salıverildiler (Lescot, 1993:45). İç çelişkilerden de faydalanan şeyh, 1937'de neredeyse tüm bölgeyi kontrol edebilecek hale geldi (Lescot, 1993:37). Müritlerin her şeyi kontrol altına almasıyla Afrin bölgesi adliye, maliye, askeriye organları bulunan İslamî ilkelere bağlı bir yönetim halini almıştır (Soğukoğlu, 2011: 20). Hareket güçlenince toprakları zorla elinden alınanların topraklarını geri almak, zorbalığa uğrayanları desteklemek amacıyla bazı saldırılar düzenlemeye başlandı. Bazen şeyhin dostlarıyla birlikte katıldığı silahlı eylemlerin çoğu Reşid İbo tarafından gerçekleştirildi. Kendi kurallarını zorla icra etme, zorla vergi alma, ağalara ait arazi ve şahsi malların zaptı vb. olaylar 1937-38'de günlük faaliyetler haline geldi. Mürit sayısının giderek artması tedirginliğe sebep oldu (Lescot, 1993:34-35). 1936 yılı sonundan itibaren bir araya gelmenin kendi menfaatlerine olduğunu anlayan ağalar birlikte bir çok

${ }^{9}$ Kör Reşid (Reşidé Kor) söz konusu dönemde Kürt Dağı bölgesinin en güçlü ağasıdır. Kürt Dağı'na yerleşimi sırasında Soğukoğlu'nu himaye eden fakat daha sonraları araları açılan bölgenin en etkili ailesi Şeyh İsmailzade ailesine mensuptur. Yerel kanyaklara göre Kör Reşid ile müritler arasındaki düşmanlık Suriye genelinde Vatan Kitlesi'nin kazandığı 1936 seçimleri sırasında ortaya çıkmıştır. Söz konusu seçimlerde müritler mecliste Kürt Dağı temsilciliği için yarışan Kör Reşid'e karşı zengin toprak sahibi başka aileye mensup bir memur olan Hüseyin Avni'yi desteklemişlerdir. Kürt Dağı bölgesindeki en güçlü kişi olan Kör Reşid uzun yıllar boyunca bölgeye hükmetmiştir. Kör Reşid ayrıca Kürt milliyetçi örgütü Hoybun ile ilişki içinde olmuştur (Lange, 2010:412-413). Kör Reşid ile Hüseyin Avni’nin arasındaki karşıtlıkta/düşmanlıkta kabilevi unsurlar da etkili olmuştur. Söz konusu karşıtlık aslında bir parça Kör Reşid'in kabilesi "Biyan"lar ile Hüseyin Avni’nin ailesi “Şehan”ların (Şéxan) arasındaki çatışmanın devamıdır. 1936 seçimlerinde Hüseyin Avni'yi destekleyen müritlilerin arasında da "Biyan"lara oranla "Şehan"lardan daha fazla mürit bulunmaktadır (Lescot, 199:37). Seydo Diko'nun kabilesi Amkanlar ('Amkan) "Biyan”ları desteklemektedir (Lescot, 199:56). Bölgedeki bu vb. düşmanlık ve çelişkilerin müritleri güçlendirdiği açıktır. Birçok olayın akabinde, 1938'de dahi bazı ağalar Şeyh İsmailzadeleri zayıflatmak amacıyla şeyh ile barışa hazır olduklarını göstermişlerdir (Lescot, 1993: 38). Mürit Hareketi de bölgedeki bu sosyal karşıtlıklardan ve düşmanlıklardan etkilenmiş ve faydalanmıştır.

${ }^{10}$ Kürt Dağı bölgesinde zengin toprak sahibi bir aileye mensup bir memur olan Hüseyin Avni 1931 ve 1936 seçimlerinde Kürt Dağı bölgesinin temsilcisi olarak Suriye parlamentosuna seçilmiştir. 1936 seçimlerinde ikinci aday olarak Kör Reşid'e karşı yarışan Hüseyin Avni’nin seçilmesi müritlerin desteğine bağlanmıştır. Kendisine karşı yarıştığı Kör Reşid gibi Hüseyin Avni'de Kürt milliyetçi örgütü Hoybun ile temas içinde olmuştur (Lange, 2010:412). Müritler ile Hüseyin Avni arasındaki ilişki öncelikle karşılıklı bir fayda ilişkisi olarak görülebilir. Hüseyin Avni kendi çıkarları için müritlerden faydalanmak isterken müritlerde bazı güçlü kişilerin, desteğini alarak kendilerine karşı olan ağaların gücünü parçalamak arzusundadırlar. Fakat bu karşılıklı yakınlaşma kısa sürmüştür; zira iki tarafta birbirine güvenmemektedir (Lescot, 1993: 33). Lescot'a göre kolayca değişim gösterebilen Hüseyin Avni bazen Türkler bazen Fransızlar bazen de Araplarla ilişki içinde olmuştur. Müritlerle de kurmuş olduğu iyi ilişkileri 1938'e kadar sürmüştür (Lescot, 1993: 37). Hüseyin Avni, 1938'de bölgenin ileri gelenlerini Kürt Dă̆ı'nın Türkiye’ye katılımını teşvik etmek için Türkiye tarafından desteklenmiştir (Lescot,1993: 43). 
toplantı yaparak (Lescot, 1993:37) harekete karşı önlem almaya ve nüfuzlarını korumaya çalıştılar.

Şeyhin faaliyetlerini ve hareketin özellikle 1936'dan itibaren niçin güçlendiğini anlamak için dönemin gelişmelerine bakmak gerekmektedir. 9 Eylül 1936' da Suriye ile Fransa arasında Suriye' deki manda yönetimini sona erdiren bir anlaşma yapılmıştır. 29 Mayıs 1937'de Türkiye ile Fransa dışişleri bakanları Cenevre'de İskenderun Sancağı'nın toprak bütünlüğ̈̈ ile Türkiye-Suriye sınırlarını güvence altına alan antlaşmalar imzaladılar. 1937'de Fransa mahalli idarelerin Suriye'ye bağlanmasını kabul etti. Bu süreçte Türkiye, Hatay'ın Türkiye'ye katılması ve Suriye'den sayılması için yoğun çaba harcamaya başladı. Diğer taraftan Suriye milliyetçileri ise 1936-39 arası dönemde Suriye devletinin Arap karakterini güçlendirmeye çalıştılar. Fuccaro'ya göre 1936'da, Suriye siyasetinde yaşanan bu beklenmedik değişiklik, Arap milliyetçiliğinin yükselişinin diğer gruplarda yarattığ hızla çok sayıda Kürdü harekete geçirdi (Fuccaro, 2005:253). Lescot'a göre müritleri destekleyen Türkler 1936'da Kürd Dağı'nın Türkiye'ye katılmasını teşvik etmek için ağalarla da ilişki kurdular. Seydo Diko aracılığı ile onlara para ve silah verdiler. Sancağın Türkiye'ye katılmasından sonra da Kürd Dağı'nın Türkiye'ye katılmasını teşvik ve bölgenin önde gelenlerini ikna etmek için Hüseyin Avni ile ilişki kurmaya devam ettiler (Lescot, 1993:43). Abdurrahman Melek'in hatıralarında bahsettiği Kürt aşiret reislerinden Koço'nun Türkiye taraftarı olarak çalışmak istemesi vb. örnekler de bu minvalde okunabilir (Melek, 1991:31).

Gerçekte Türkiye Hatay'ın Türkiye'ye katılması sürecinde Kürtlerin de desteğini almaya çalışmıştır ki bu durum Türkiye'nin Hatay meselesinde Arap milliyetçilerine karşı Kürtleri kendine yakın gördüğünü göstermesi bakımından anlamlıdır. Bu dönemde Kuzey Suriye'de Halep civarında önemli bir nüfus gücüne sahip olan Kürtlerin Türk yanlısı olmalarının sağlanarak Suriyeli milliyetçilerin ve Fransız mandasının baskı altına alınması Türkiye'nin mevcut stratejisi olarak görünmektedir (Demir, 2012: 53). Bu amaçla söz konusu dönemde mezhepsel ayırım ifade eden beyanatlardan da kaçınılmış, resmi beyanatlarda Nusayriler de Eti Türkü olarak kabul edilmiştir (Demir, 2012: 66). Daha genel çerçevede Türk milliyetçiliğinin de fazlaca öne çıkartılmadığını, aksine Arapları da içerecek şekilde Sünnilik çerçevesinde bir işbirliğinin olduğunu görmekteyiz. Sünni olan Çerkez ve Kürtlerin ve bazı Arapların Türk listelerinde yazılması bu ittifakın en sarih bir göstergedir (Demir, 2012: 70-71). Nüfus gücü milletvekili çıkarmalarına yetmesine rağmen ilginç bir şekilde Kürtlere temsiliyet hakkı ne Cemiyet-i Akvam'da ne de Kürt ileri gelenlerince dile getirilmemiştir (Demir, 2012: 69).

Hatay'ın Türkiye katılması ve Suriye'den sayılmaması için yoğun çaba harcandığ 1 bu dönemde şeyhin, Suriye'nin kuzeyindeki nüfuzunun farkında olan Türkiye 3/2/1937 tarihinde Bakanlar Kurulu kararnamesiyle şeyhi serbest birakarak Ankara'ya çağırdı (Başbakanlık Cumhuriyet Arşivi, Kararname, 3.2.1937, 5986). Hatay meselesine ilişkin olan temasların akabinde referandumda bölgenin Türkiye'ye katılımını teşvik etmek amacıyla bölgeye gönderildi. Yetkililer Mürit Hareketi'nin Hatay'ın Türkiye'ye bağlanmasında etkili olabileceğini düşünmüşlerdir (Soğukoğlu, 2011:21). Bu husus dönemin Emniyet Genel Müdürü (Emniyet Umum Müdürü) olan Şükrü Sökmensüer tarafından doğrulanmıştır. Sökmensüer, konuyu (ö. 1978) şu şekilde dile getirir: "Hatay nüfusuna 
kayıtlıymış gibi, iki maliye müfettişini de oraya gönderdik. Bunların arasında bir de meşhur Nakşibendî şeyhi ki, Atatürk çok severdi” (İnan, 1997: 91). Burada Hatay Erginlik Cemiyeti'ne bir dönem başkanlık eden İbrahim Halil Efendi daha sonra Hatay Cumhurbaşkanı olacak olan Tayfun Sökmen ile de iyi ilişkiler kurdu (Soğukoğlu, 2011:21). Zaten Tayfur Sökmen de cemiyetin Dörtyol şubesini idare etmiştir. Abdurrahman Melek'e göre kendisi Hatay görüşmeleri için Cenevre'de iken İstanbul, Dörtyol ve Mersin'de kurulan bu cemiyet Ankara'daki Hatay Egemenlik Kurumu'na bağlı olacaktı (Melek, 1991:36-37). Faaliyetleri Ankara tarafından yönlendiren bu cemiyet (Çiğdem, 2008:106) bölgenin Türkiye'ye katılması adına çaba göstermiştir (Çiğdem, 2008:4). Yukarıdaki anlatım vs. dikkate alındığında cemiyetin dönemin Hatay işleri ile yakından ilgilenen istihbarat teşkilatı olan Millî Emniyet Hizmetleri'ne (MAH), Sökmensüer'e bağlı olduğu anlaşıllyor. Gerçekte Emniyet Genel Müdürlüğü ve MAH söz konusu dönemde Hatay'ın Türkiye'ye katılması için yoğun bir faaliyet için girmişlerdir. Hatay'a yönelik faaliyetler esas olarak $\mathrm{MAH}$, emniyet ve halkevleri tarafindan organize ve idare edildi. Bölgedeki gelişmeleri ve Türkiye'ye dönük faaliyetleri sürekli olarak takip eden MAH, özellikle 1936'dan itibaren bölgenin siyasi, etnik, iktisadi, sosyal yapısını ortaya koyan ayrıntılı raporları merkeze göndermiştir (Yorulmaz, 1998; Pehlivanl1, 1999:155). Daha yakın bir örgütlenme olarak söz konusu cemiyet, Halkevleri'nin direktif ve yönlendirmeleri doğrultusunda faaliyete bulunmuş görünüyor (Payasl1, 2011:230). Hatay'daki Halkevleri'nin bir propaganda kolu bulunmaktaydı (Konuralp, s.152). Söz konusu dönemde Türkiye'nin lehine propaganda yürütmek amacıyla gönderilen başka kişilerde olduğunu dönemin tanıklarından öğreniyoruz (Konuralp, 1973: 153). Fakat Halil İbrahim Efendi'yi bizzat tanıyan ve döneme dair hatıralarını kalem alan kişiler, döneme dair birçok teferruat bilgiye ve isme yer verirken ilginç bir şekilde Halil İbrahim Efendi'nin adını hiç anmamışlardır.

1938 Temmuzunda ailesi ile birlikte Halep'te ikamet etmeye başlayan şeyh tekrar Fransa karşıt1 faaliyetlerin içine girdi. ${ }^{11}$ Suriye'nin önde gelen siyasiler, milliyetçi liderler de ona yakınlık gösterdiler ve onu barındırdılar (Lescot, 1993:39, 45). İbrahim Halil Efendi bölgede daha önce ilişkide olduğu bazı dini kişilikler ve Vatan Kitlesi'nin yetkilileriyle görüşerek özellikle lojistik, mühimmat konusunda destek ve yardım sözü aldı (Soğukoğlu, 2011: 22). ${ }^{12}$ Vatan Kitlesi ve hükümetin

\footnotetext{
${ }^{11}$ Lescot'a göre şeyh kendisine emniyetten gelen emir üzerine Suriye geçti. Lescot bu iddiasına kanıt olarak Emniyet Genel Müdürlüğü’nden şeyhi yargılayan Bilecik mahkemesine gönderilen 29402 sayılı, 14.6.1939 tarihli istihbari yazıdan bahseder. Ona göre yazı mahkemenin Halil Efendi hakkında verdiği 14.3.1940 tarihli karar dosyasında yer almıştır. Ve bu yazının bir kopyası Halep'te şeyhin dostu Ahmed Seydavi'nin yanında bulunmuştur (Lescot, 1993:41). Fakat Lescot'un bu evrağın suretini çalışmasına koymadığını da belirmek gerekir. Diğer taraftan sözlü tanıklarda olayların durulmasından sonra Halil İbrahim Efendi'nin uzun süre bölgede kaldığını, şeyhlik iddiasını Kilis, İslahiye ve köylerinde devam ettirdiği, hatta hala taşıdığı resmi görevinin de kendisine verdiği güçle çeşitli kanunsuz hareketlere yöneldiği söylenmektedirler (Öztürk, 2005: 44). Şeyhin Atatürk tarafından gönderildiğini söyleyen tanıklara göre şeyh kendisini binbaşı olarak tanıtmıştır. Resmi görevden kastedilen budur.
}

${ }^{12}$ Lescot'a göre Suriye hükümeti müritlere yakınlık göstermekten uzak durmadı. Onlara silah verdiği gibi jandarmalarını onları rahat bırakması konusunda uyardılar. Müritler karakolların telefonunu rahatlıkla kullanmaktaydılar. Reşid İbo 1937'de tutuklanınca resmi ve rutin bir tahkikatın akabinde serbest bırakıldı. Yöneticilerin müritlerle ilişkileri Halep'te Abdo Mısri ve Necib Üveyd üzerinden sağlanmaktaydı (Lescot, 1993:39). F. Soğukoğlu'da bazı kaynaklara istinaden şeyhin Vatan Kitlesi'ne mensup Abdo Misri ve Necib Üveyd, Fatih Mar'aşi ve hatta Suriye İçişleri Bakanı Sa'dullah Cabiri ile bir araya gelerek gizli anlaşmalar yaptığını ve 
desteklediği müritler tavırlarını daha da keskinleştirdiler. Şeyh, ekim ayında yeniden gelip Afrin'de yerleşti ve silahlı taraftarlarının desteğiyle kendi düzenini kurmaya başladı. Müritler bölgede kendi hukuklarını uygulamaya, köylerden vergi almaya, ağaların topraklarına el koymaya, bölüştürmeye ve düşmanlarını öldürmeye başlayarak bölgede büyük bir korku saldılar. Söz konusu eylemler çoğunlukla Şeyh İsmailzadelere ait olan köylerde gerçekleştirildi. Hareketin Afrin ve Azez'e uzandığı gören Men'an Niyazi gibi bazı ağalar buna karşı adamlarını silahlandirdilar (Lescot, 1993:46, 34). ${ }^{13}$ İbrahim Halil Efendi, Vatan Kitlesi ile anlaştığını ve tüm Suriye'ye yayılacak bir hareket başlatacaklarını söyleyerek ağaların desteğini almaya çalıştı. Fakat Fransa ile ittifak kuran ağaların desteğini kazanmakta başarısız oldu (Soğukoğlu, 2011:22). Müritler ile ağalar ve Fransızlar arasında pek çok çatışma yaşandı. Bu arada 1938 yılı sonuna doğru şeyhi destekleyen Vatan Kitlesi'nin en azından bir kesimiyle müritlerin arası soğudu (Lescot, 1993:39). Bunda asıl etkenin Hatay'ın Eylül 1938'de bağımsız bir cumhuriyete dönüşmesinin etkili olduğu açıktır. Söz konusu gelişme ve akabinde de Hatay'ın Türkiye'ye katılması (1939) Vatan Kitlesi yöneticilerinin hareket aleyhindeki düşüncesini güçlendirmiştir.

Durum yerel yöneticilerin göz ardı edemeyeceği bir hal alınca Kasım ayında Halep'teki yöneticiler meseleye al att1. Suriye yöneticileri Jandarma genel komutanı Behiç el-Hatib'i bölgeye gönderdi (Lescot, 1993:47). 18 Şubat 1939'da Vatan Kitlesi kendi için de Hatay meselesi sebebiyle düştü. Ulusal hükümetin düşmesiyle Fransizlar meseleye müdahale etmek ve Mürid Hareketi'ni bitirmek için fursat buldular (Lescot, 1993: 47). 28 Şubatta Şeyh Hanif jandarmalarca tutuklandı. Mart ayında bir tabur asker Kürt Dağı'nı temizlemek üzere yola çıktı (Lescot, 1993:47). Fransız Hava Kuvvetleri bildiri dağıttıktan sonra müritlerin köylerini uçaklarla bombalamaya başladı. Suriye jandarması ve ağalar silahlı adamlarıyla harekata destek verdi. Çatışmalar yaşanırken Soğukoğlu'na göre Vatan Kitlesi olaylara seyirci kalır (Soğukoğlu, 2011: 23). Lescot ise aynı kanaate değildir. Ona göre 1939 İsyanı'nda Kürt Dağı milliyetçiler tarafindan Şam'dan çalınan Fransız silahlarıyla doluydu ve Suriye yönetimi kendilerine karşı gönderilen Fransız taburuna karşı Kürt direnişinin tüm kuzey Suriye direnişin sembolü olacağını düşünmekteydi. Yine ona göre Türkiye'de harekete destek vermiştir (Lescot, 1993:39). 1939' da müritlerin üzerine asker gönderildiğinde bazı Türk subaylar müritlere yardım ederek sınırı geçmelerini kolaylaştırdı (Lescot, 1993:41). Sonuçta yaşanan çatışmalardan sonra şeyh birkaç müridiyle birlikte Türkiye'ye geçti. Cezalandırılmaktan korkan çok sayıda köylü de müritlerle beraber sınırı geçerek Türkiye'ye iltica etti (Lescot, 1993:47, Öztürk 106). 18 Mart 1939 tarihinde Türkiye sınır kapılarını bu mültecilere açtı. Bu Türkiye Cumhuriyeti Devleti tarihinde Türkiye'ye ilk iltica hareketidir (Öztürk, 1995:45) Yaşanan olaylara tanık olanların anlatımı da aynı minvaldedir. Tanıklara göre

Cabiri'nin şeyhe her türlü maddi ve manevi destek söz verdiğini ifade eder (Soğukoğlu, 2015: 252).

${ }^{13}$ Meydanké köyünde 30 Eylülde Şeyh İsa'nın oğlu öldürüldü. Ayrıca Cemil Ağa (Yezidilerin lideri), Kör Reşid, Faik Ağa ve Seydo Diko'yu öldürmek istediler. Ayrıca Seydo Diko'nun torunu Hasan'1 (Heso) öldürdüler (Lescot, 1993:46). Söz konusu dönemde Bülbül mıntıkasında geniş topraklara sahip olan Faik Ağa, Kürt Dağı'nın politik yaşamında son derece etkili olmuş bir kişiliktir. Belediye başkanlığını müteakip 1943’te Suriye parlamentosuna Kürt Dağı temsilcisi olarak seçilmiştir. Hem Faik Ağa hem de belediye başkanı olan halefi Halil Ağa, Celadet Ali Bedirhan'ın yayınladığı Hawar dergisinin destekçilerinden olmuşlardır (Lange, 2010:412). 
1938 yılının şubat-mart aylarında "Müritlerin Harbi" başladı. Fransızlar, ağalarla birlikte askeri kuvvetler eşliğinde kuzeye doğru harekete geçtiler. Fransızların bombaladığı sınır köylerinde şiddetli çatışmalar yaşanırken çok sayıda köy halkı sınıra yığıldı. Türkiye çok sayıda kişinin mülteci olarak sınırı geçmesine izin verdi. $\mathrm{Bu}$ arada sınırın karşındaki bazı köylerde sınırda müritlere ateş desteği vererek sınırı geçmelerini sağlamış, bazıları müritlerin yanında çatışmalara katılmışlardır. Bir grup mürit, Deli Osman köyündeki askeri bölügün müdahalesiyle kurtarılmış, askerler Fransızları takiben 5-10 km içeri girmişlerdir. Çatışmalar yaz boyunca devam etmiştir. Mültecilerin bir kısmı geri dönerken Türkiye'de kalanlar ise T.C vatandaşlığına geçirilmiş, Kilis, İslahiye ve Kırıkhan çevresine yerleşmişlerdir (Öztürk, 1995: 20-21; 2005: 45; Lescot, 1993:42). Resmi kayda göre 3759 mülteciden Suriye dönmek istemeyen 1206 kişinin yerleşme talebi kabul edilmiş, fakat mültecilerden Kürt ve Arap olanlar için belirli yerlere yerleşme/yerleşmeme şartı getirilmiştir (Başbakanlık Cumhuriyet Arşivi, Kararname, Haziran 1941, 16033). Lescot'a göre Türkiye'nin mültecileri barındırmaktaki amacı mültecileri bahane ederek Kürt Dağı'nın Türkiye'ye katılmasını sağlamaktı (Lescot, 1993:48). Aşağıda aktaracağımız devlet yetkililerinin beyanları da Türkiye' nin Kürt Dağı bölgesinin ilhakı ihtimalini göz ardı etmediğini doğrular niteliktedir. Dahası sözlü tanıklara göre şeyhin devletin adamı/ajanı olduğu ve bölgenin Türkiye'ye ilhakı için gönderildiği destekçileri dahil sınırın Türkiye tarafındaki yerel halk arasında bilinen/konuşulan bir husustu (Çelebioğlu ile Mülakat, 2, 2, 2016).

\section{1940 ve Sonrası Dönem Mürit Hareketi}

Bir süre Kilis'te tutulan İbrahim Halil Efendi sonra Bakanlar Kurulu kararıyla Bilecik'te zorunlu ikamete tabi tutuldu (Başbakanlık Cumhuriyet Arşivi, Kararname, Haziran 1941, 16033). Şeyh müritleriyle iletişimini gizlice sürdürür. Fransızlar, savaş öncesi Kürt Dağı halkından olan müritlerin örgütlenmesinde önemli rol oynayan ve Fransızlarla çatışmasına katılan bir Türk astsubay olan Bekir Fehmi (Lescot, 1993:41) ${ }^{14}$ ve Şeyho Seydo ile bazı görüşmelerde bulunarak anlaşmaya çalışırlar. Görüşmelerde Fransız general müritlere bölge halkının hepsinin Kürt olduğunu ve Arapların kendilerine yaptıkları mücadelede hiç yardımlarının olmadığını belirterek müritlerin silah bırakması halinde onlarla özel anlaşma yapmak istediklerini belirtirler. Fakat müritler bu anlaşmaya yanaşmayarak (Soğukoğlu, 2011:28) Fransız karşıtı mücadeleye devam ederler.

Suriye'de yaşanan olaylar üzerine şeyh, 5 Mayıs 1940'ta zorunlu iskan yerinden ayrılarak/kaçarak Kürt Dağı'na gider (Başbakanlık Cumhuriyet Arşivi,

\footnotetext{
${ }^{14}$ Lescot ayrıca Soğukoğlu ve müritlerin sürekli ilişki içinde oldukları (önceleri Hassa'da daha sonra Hatay'da görev yapan) Tayfur Bey ve Haydar Bey isimli subaylardan bahsetmektedir (Lescot, 1993:41). Bekir Fehmi'nin herhangi bir askeri kimliğinin olup olmadığından bahsetmeyen F. Soğukoğlu'na göre Bekir Fehmi, İslahiye’ye bağlı İdilli köyündendir. Asıl adı Bekir Karaya'dır ve Fehmi adı da İbrahim Halil Efendi tarafından kendisine verilmiştir. Bekir Fehmi, İbrahim Halil Efendi'nin "halifesi”, “önde gelen mürit”lerinden, “müritlere komuta etmiş mücahit”tir. Şair yönü de bulunan Bekir Fehmi, "bakın bize ey asiyan biz zümre-i nacileriz" dizesiyle başlayan "Müritlerin Marşı”nın da yazarıdır. 1942 yılında öldürülmüştür. Bkz. Fehmi Soğukoğlu, "İbrahim Halil Efendi'nin Gaziantep/İslahiye'deki Dini Hayata Katkısı”, Gaziantep'te Dini Hayat, içinde, Gaziantep Büyükşehir Belediyesi Kültür Yayınları, Gaziantep, 2017, s. 901-902. İbrahim Halil Soğukoğlu, Kenz-i Şumus isimli divanında Bekir Fehmi’nin bazı manzumelerine de yer vermiştir.
} 
Kararname, Haziran 1941, 16033). Müritlerine de Suriye'ye dönmelerini emreder. Zaten ailesi de buradadır. Şeyh, burada Fransızlara Türkiye'den gönderiyormuş gibi birçok mektuplar yazarak yeniden görüşmeye çalışır. Zira önceki görüşmeler kontrolü dışında istemediği şekilde sonuçlanmıştır. İbrahim Halil Efendi'nin amacı Almanya'nın Fransa'yı işgal etmesiyle Suriye'den çıkmak zorunda kalacak olan Fransızlarla bölgede kendilerinin söz sahibi olacağı bir anlaşma yapmak olmalıdır. Musa Na'sân Efendi ve bazı kaynaklar onun Fransızlardan Kürt Dağı bölgesi için özerklik istediğini zikreder (Soğukoğlu, 2011:28). Sözlü tanıkların da ifadesine göre de İbrahim Halil Efendi'nin amacı bölgede Hatay'da olduğu gibi bir halk oylaması yapılmasını sağlamaktı. Şayet ağalar Fransızlarla birlik olmasaydı muhtemelen böyle bir halk oylaması yapılacaktı (Öztürk, 1995:21; 2005: 45). Zaten Fransizlar daha erken bir tarihten itibaren İbrahim Halil Efendi'nin Türkiye tarafından Kürt Dağı bölgesini Türkiye'ye katmak için gönderildiğini düşünmekteydiler. Sözlü tanıklarda lehine olarak Halil Efendi'nin Atatürk tarafindan gönderildiğini ifade etmekte ve buna inanmaktadırlar (Öztürk, 1995:18). İbrahim Halil Efendi'nin Suriye'ye ikinci gidişi/gönderilişi ve halkın onun amacı hakkında bilgi sahibi oluşu dikkate alındığında şeyhin amacını halka, en azından yakın çevresine deklare ettiği sonucuna varmak mümkündür.

Söz konusu dönemde Türkiye'de yakından takip edilen Arap kamuoyu da benzer düşünceler yaygındı. İskenderun ve havalisinin Türkiye tarafından ilhak edilmek üzere olması Suriyelileri telaşa düşürüyordu. Büyük Suriye toprakları içerisinde addettikleri İskenderun'un Türkiye tarafından alınması ve Türkiye'nin İskenderun'dan sonra Halep ve civarı için de aynı faaliyetlerde bulunma ihtimali Suriyelileri düşündürmekteydi (Hourani 1968: 161). Aslında Suriyeliler endişelerinde haksız sayılmazdılar. El-Ahram gazetesi Türkiye'nin Halep'i almak istediğine dair düşüncelerini bizzat dönemin Dış İşleri Bakanı Tevfik Rüştü Aras'ın beyanına dayandırmıştır (Topal, 2009: 5). Milletler Cemiyeti Konseyi'nin 27 Ocak 1937'de Sancak'1 “ayrl bir varlı"' olarak kabul etmesi sonras1 Türkiye'nin yakından izlediği Arap basınından El Ahram gazetesinin Cenevre'den yazan, Türkiye'nin Suriye'yi parçalamak, Suriye ve Lübnan üzerinde hüküm sahibi olmak istediğini düşünen muhabiri, Miletler Cemiyeti'nin son toplantıları sırasında Tevfik Rüştü Aras, Abdurrahman El Keyyalî ve İhsan El Cabirî arasında geçen bir diyalogu aktarır. Buna göre Suriyeli görevlilerin "Ĕger Sancak hakkındaki Ankara dilekleri tahakkuk ederse, artık Halep için yaşamak ihtimali kalmaz" sözleri üzerine bunları sükunetle dinleyen Aras "o halde Halep bizim olacaktır" ş̧eklinde cevap vermiştir. Muhabire göre bu sözler Türklerin kafasındaki düşüncelerini ortaya koymaktaydı. (Başbakanlık Cumhuriyet Arşivi (BCA), 490.01.588.31.1-65 ve 66). Yine aynı y1l bölge gazetelerinde Türkiye'nin Halep'i de alacağı, Hama şehrinin kuzeyindeki Suran köyünün kuzeyinden Ürdün'ün güneyine kadar olan alanın Türkiye'nin etkisine gireceğine dair haberlerin çıkması üzerine dönemin Dahiliye Vekaleti Vekili Saffet Arıkan, “zaten Türkiye'nin misak-ı millisi Basit burnunda Ördek gagası (bec de Canard) denilen yere çekilen hatt müstakimin şimalindeki araziden bahseder. Hududu Suran'dan itibareden halk buna dini kadar inanmıştır" şeklinde beyanda bulunması da Türkiye'nin bölgeye olan ilgisini ortaya koyan bir diğer örnektir (Cumhurbaşkanlığı Arşivi, A 4-18-e, D 74-1, F 19-6, 13 Temmuz 1937 tarihli, Dahiliye Vekaleti Vekili Saffet Arıkan'ın Riyaset-i Cumhur Katib-i Umumiliğine raporu'dan aktaran Demir, 2012:65) Dönemin önde gelen Arap aydınlarından Şekip Arslan'da 31 Ocak 1937 tarihli El Eyyam gazetesinde yayınlanan "Bundan Sonra "Suriye Milletine, Hükümetine, Matbuatına Düşen Vazife" başlıklı 
yazısında Cenevre ittifakından Türklerin karlı çıktı̆̆ını, Türkiye'nin propaganda kapısını açtığını, bununsa Arapların şerefini tehdit ettiği ifade etmiştir. Arslan'a göre "Arap birliği korkusuyladır ki Türkler, Sancak meselesinde dünyayı velveleye verdiler. Bununla asıl aradıkları, Sancağın Suriye dışında kalmasını temin etmek, günün birinde Haleb'i de sikıştırıp ilk firsatta ele geçirmektir." Arslan, bölgede Türkiye'nin nüfuzunu kırmak gerektiği ifade ederek alınması gereken önlemler üzerinde durur (Topal, 2009: 5-6). Bu arada Türkiye, Arap kamuoyunda olup bitenleri yakından izlemektedir. Hem Suriyeliler hem de Fransızlar bu dönemde Türkiye'nin savaş şartlarını değerlendirerek bir harekat yapmasından endişelenmekteydiler. Fransız istihbaratı Ankara'nın Suriye'deki Türkler, diğer ayrılıkçı unsurlar ve bazı Suriyeli politikacılarla irtibat içinde olduğunu rapor etmekteydi (Thomas 2005: 324-326).

Buraya kadar aktarılanlardan anlaşıldığı kadarıyla söz konusu dönemde Türkiye Hatay'ın Türkiye'ye katılımıyla yetinilmişse de daha fazlasının, Kürt Dağı'nın (ve belki de tüm kuzey Suriye'nin) Türkiye katılımını amaçlamış görünüyor. $\mathrm{Bu}$ sebeple şeyhin bölgedeki faaliyeti sadece Hatay'ın Türkiye'ye katılımını kolaylaştıran bir koz ve stratejiden daha fazlasını ifade ediyor gibidir. Fakat II. Dünya Savaşı öncesi yaşanan gelişmeler, ülkenin askeri ve siyasi imkan ve kabiliyetleri gibi reelpolitik nedenlerle Hatay'ın alınmasıyla yetinilmiştir. Lescot'a göre Kürt Dağı'nın Türkiye topraklarına katılmasını amaçlayan Türkiye, Fransızların Mürit Hareketi'ne müdahalesi ve Balkanlardaki belirsizlik sebebiyle bir süre planlarından vazgeçmiştir (Lescot, 1993:48-49) Müritlerin bölgedeki silahlı faaliyetlerinin Hatay'ın bağımsızlığı ve ilhakını müteakip devam etmesi, Kürt Dağı'nın dahil olduğu Halep mıntıkası ile ilgili resmi beyanlar vs. gerçekleşmemiş olmakla birlikte Kürt Dağı'nın Türkiye dahil edilmesine dönük bir isteğin mevcudiyetini doğrular niteliktedir. Söz konusu dönemde Türkiye'nin siyasal konjonktüre bağlı olarak çeşitli politik hamlelerle sınırlarını genişletme, bazı noktalarda Misak-1 Milli'ye ulaşma çabaları olduğugörülmektedir.

İbrahim Halil Efendi'ye dönersek, özerklik konusunda Fransızların daha önce müritleri muhatap almalarından ötürü ümitli olmalıdır ki bir daha Türkiye'ye dönmeyecekmiş gibi bütün ailesiyle beraber Suriye'ye geçmiştir. Bütün bu düşüncelerle ağalara mektuplar ve haberciler göndererek mevcut durumun eskiye göre çok farklı olduğunu, Fransızların Suriye'den çıkacaklarını ve Fransızlara karşı ellerinin güçlü olması için eski düşmanlıkları bırakarak birlik olmaları gerektiğini bildirir. Fakat şeyhin girişimleri neticesiz kalır. Müritlerin bölgeyi terk etmesi şeyhin nüfuzunu azaltmıştır. Şeyh bir süre sonra müritlerin bölgesine geçer, bu sefer müritlerin karargahı sınırın Türkiye yakasıdır. Halil Efendi gücünü göstermek amaciyla Afrin'deki Raco Nahiyesi'nde bulunan Fransız birliğine saldırıda bulunur; ancak, bu saldırı da neticesiz kalır ve bir süre dağda ve Halep'te gizlenir. ${ }^{15}$ Ailesine göre şeyhin zorunlu ikamet yerinden kaçarak Suriye'ye bu son gidişi Türkiye Cumhuriyeti Devleti'nden tamamen bağımsız olarak

\footnotetext{
15 Lescot'a göre Fransa'nın Avrupa'daki kayıplarından sonra Türkiye, Kürt Dağı'nda yeni ayaklandırmalar çıkarmak istedi. Şeyh tanınan bir jandarmayı öldürdükten sonra hızla Türkiye’ye geçti ve sınırda mürit çeteleriyle birlikte sık sık görünmeye başlandı. Askerler ve silahlı müritler arasında birkaç küçük çatışma yaşandı. Şeyh, Temmuz ayının 15'inde Meydan Ekbese, 2627'sinde ise Memala köyüne saldırdı. Fakat bir yandan üzerine bir askeri birlik gönderilmesi öte yandan Balkanlardaki belirsizlik sebebiyle Türkler bir süre planlarından vazgeçtiler. Sınırda birkaç ay boyunca herhangi bir olayın yaşanmaması üzerine şeyhin sınırdan uzaklaştırıldığı anlaşıldı (Lescot, 1993:49).
} 
gerçekleşmiştir (Fehmi Soğukoğlu ile mülakat, İstanbul, 14.8.2012). Bu sebeple Türkiye tarafindan yakalandığı takdirde zor durumda kalacağını bilen İbrahim Halil Efendi, tanıdığı bazı hükümet yetkilileri aracılığ ve yetkililerinden Türkiye'ye dönmesi halinde Suriye'de Fransızlara karşı giriştiği mücadeleden dolayı herhangi bir yargılamaya tabi tutulmayacağına dair yazılı ve sözlü taahhüt almıştır. Bundan sonra bir süre daha Türkiye'ye gayri resmi olarak girip çıkmaya devam eden Halil Efendi 3 Mayıs 1941'de Kilis'te yolda jandarmalar tarafindan tutukland. Kendisini tanıyan yetkililerin de araya girmesiyle sadece on beş gün ruhsatsız silah taşıma suçlarından hapsedildi. 14 Haziran 1941'de Bakanlar Kurulu kararıyla Manisa' da zorunlu ikamet etmesine karar verildi (Başbakanlık Cumhuriyet Arşivi, Kararname, Haziran 1941, 16033). Kendisine devlet arazisinden toprak tahsis edildi ve bir çiftlik verildi. Burada tasavvufi kimliğini gizlese de müritleriyle ilişkisini devam ettirir. Kendisinden sonra tarikat işlerini emanet ettiği Musa Na'sân Efendi gibi bazı müritleri burada eğitmeye devam eder. Manisa halkı şeyhin arazisinde çalışanların çoğunun Kürt olması sebebiyle ona "Kürt Beyi” lakabını takarlar. Güzel Kur'an okuması sebebi ile "Hafız Efendi" diyenlerde vardır (Soğukoğlu, 2011:28-31).

Demokrat Parti'nin (DP) iktidara geldiği 1950'li yıllında İbrahim Halil Efendi'ye serbest dolaşım hakkı verilmiş, fakat bir süre sonra hakkında tekrar Manisa dışına çıkma yasağ 1 konmuştur. Şeyh, 24 Nisan1952'de Manisa'da azmettiricisi bilinen kiralık katillerce öldürüldü/öldürtüldü. Aile efradının beyanına göre daha önce İbrahim Halil Efendi dönemin İçişleri Bakanı Manisalı Feyzi Lütfü Karaosmanoğlu (ö. 1978) ve yakınlarının bazı hukuksuz işlerine şahit olunca kendisinin ve bazı mağdur köylülerin hukukunu korumak için onları mahkemeye vermiş bu sebeple tehdit edilmiş, silahlı saldırıya uğramış ve hastaneye kaldırılmıştır (Soğukoğlu, 2011:31). Şeyh suikastle ilişkin olarak ailesine "beni Ankara' dan vurdular. Bu işin peşine düşmeyin" mealinde ifadelerde bulunmuştur (Fehmi Soğukoğlu ile mülakat, İstanbul, 14.8.2012).

Sonuç olarak müritlerin hareketi Hatay Meselesi'nin fazla güçlükle karşılaşılmadan çözülmesinde kolaylaştırıcı rol oynamış ve kritik bir durumdaki Fransızların fazla 1srarcı olmamalarının sebeplerinden biri olmuştur. Fransa, Hatay dahil tüm kuzey Suriye'nin bir halk oylamasıyla Türkiye'ye katılmasına razı olmaktansa Hatay'da halk oylamasına dolayısıyla Türkiye'ye katılmasına razı olmuştur. Başka bir ifadeyle Fransa Hatay’1 gözden çıkarmakla tüm Kuzey Suriye'yi kurtarmıştır (Öztürk, 1995: 21,45). Aynı şekilde Mürit Hareketi’nin Suriye'nin Fransa karşıtı mücadelesinde etkili olduğu görülüyor. Suriyeli milliyetçiler onu dini duygularla İslam dünyasındaki yabancı varlığına karşı çıkan, Suriye'deki Fransızlara karşı savaşan kutsal bir savaşçı ve bir ağalık düzeni karşıtı olarak görmüşlerdir (Abdo, 2007). Her ne kadar Vatan Kitlesi'nin bir kesimi Hatay meselesi sebebiyle harekete karşı bazı şüphelere duymuşsa da önemli bir kısmı Fransa'ya karşı direnişi sebebiyle hareketi desteklemeye devam etmiştir. İbrahim Halil Efendi'nin Suriye'deki müritlerinin bir kısmı 1946 yılında Fransa'nın Suriye'den çekilmesine kadar Fransızlarla mücadeleye etmeye devam etmişlerdir. Sekiz yıl hapiste kalan ve Suriye'de yapılan ilk seçimlerinde milletvekili seçilen hareketin liderlerinden Hanif Arabo 1947 yılında öldürülmüştür. 1939 isyanı sonrası şeyhten uzaklaşan hareketin diğer lideri Ali Galip ise 1949'da Gaziantep'te öldürülmüştür. Halil İbrahim Efendi'nin ölümünden sonra Türkiye ve Suriye'deki müritlerine Musa Na'san Efendi liderlik ettiği (Abdo, 2007) Mürit Hareketi zamanla gücünü ve etkinliğini kaybetmiştir. 


\section{Sonuç}

Mürid Hareketi'nin siyasal yönünü net olarak yorumlamak ve daha aydınlık bir resmini ortaya koymak çok kolay değildir. Mevcut kaynaklardan anlaşıldığı kadarıyla Mürit Hareketi iç içe geçen dini, sosyal ve siyasi amaçlar tarafinda motive edilmişmitir. Aslında hareket motivasyonu ne olursa olsun özellikle ilk dönemleri itibarıyla ağalık karşıtı halkçı karakteriyle modern hareketlere yakın bazı sosyo-politik idealler taşımaktadır. Diğer taraftan hareketin hem Suriye' deki Fransız karşıtı Vatan Kitlesi hem de Türkiye istihbaratıyla bazı ilişkileri olduğu açıktır. Fakat Soğukoğlu'nun istihbari organlarla olan ilişkisinin derinliği ve niceliği hakkında yeterli verilere sahip değiliz. Yakın dönemde dahi bazı tanıklar şeyhin Türk istihbaratının adamı olduğunu ya da istihbarat ile ilişkili olduğu iddialarını reddederek söz konusu iddiaların ağalar ve Fransız tarafından ortaya atıldığını söylerken (Lescot, 1993: 9-10, çevirmenin girişi) dönemin bazı tanıkları ise şeyhin kendisini "binbaşı" olarak takdim ettiğini ifade etmişlerdir (Öztürk, 2005: 44). Belki daha önemlisi Suriye'nin Bılélko köyünde şeyhin en yakınlarından Ali Galip'in ağzından Ali Galip'in yaralı olarak hastanede yatarken şeyhi bizzat asker üniforması ile gördüğünü, böylece şeyhin sırrına/sırlarına vakıf olan Ali Galip'in öldürüleceğini anlayarak, bir mektup ile ailesine bir daha dönemeyebileceğini haber verdiği söylenmektedir (Lescot, 1993: 49 çevirmenin 2 nolu dipnotu). D. Muhammed Abdo da konuya ilişkin yazısında hareketin liderlerinden Ali Galip'in 1949'da Gaziantep'te öldürülmesini şeyhin sırlarına vakıf olmasına bağlar (Abdo, 2007). ${ }^{16}$ Öztürk, sözlü kaynaklara dayanarak Halil Efendi'nin resmi bir görevle bölgede olduğunu ve hatta zaman zaman resmi görevinin de kendisine verdiği güçle çeşitli kanunsuz hareketlere yöneldiğini söylemektedir (Öztürk, 2005: 44). Bununla beraber aradan uzun yillar geçmesine rağmen şeyhten bahsedenlerin onu hala saygı ile andıklarını da belirtmek gerekir.

Gerçekte Soğukoğlu'nun bazı devlet organlarıla ve yetkili kişilerle siyasi bağlantılarının varlığı açık olmakla beraber bu ilişkilerin başlangıç tarihine ve hareketin özellikle siyasi boyutuna ilişkin daha berrak bir tablonun ortaya konulması için döneme ilişkin daha fazla kaynağa, belgeye ulaşmak gerekmektedir. Lescot, hareketin siyasi kökenlerinin sosyal kökleri kadar açık olmadığını ifade eder (Lescot, 1993:36). Türkiye'nin 1935'lere kadar şeyhin İslahiye civarında mürit edinmesine karşı çıktığını hatta Türk ajanların müritlerin Fransızların ve Ermenilerin adamları olduğunu söylediklerini ifade eden Lescot'a göre bir süre sonra bundan vazgeçerek sınır güvenliği ve Suriye'yeki faaliyetler için ondan istifade etmeye çalıştılar (Lescot, 1993:40); tarihi kesin olmamakla beraber, şeyh 1935-1936 yıllarında Türk istihbaratıyla ilişki içine girmiştir (Lescot, 1993: 40). Ancak yukarıda sunduğumuz kaynaklara dayanarak daha düşük bir düzeyde olmakla beraber Soğukoğlu'nun söz konusu ilişkilerinin tarihini daha geriye götürmek gerekmektedir. Fakat bu ilişkilerin özellikle 1936'lardan itibaren farklı bir yoğunluğa ve gayeye evrildiği de açıktır. Türkiye bölgenin sosyoloji ile etkileşim içinde gelişen hareketten istifade etme yoluna gitmiş ve bunda da başarılı olmuştur.

\footnotetext{
${ }^{16}$ Soğukoğlu'nun Kenz-i Şumus adlı divanında aralarının açıldığı Ali Galip'e yergi mahiyetinde yazılmış “Ey Mevla'nın ni'metlerini görmeyen nankör uyan/ Yedin içtin nimetlerin kılmayan münkir uyan/ Adın idi bir canavar "Galip" dedi sana Cebbar/ Aslına dön ey gaddar ey bir gözü bin kör uyan” dizeleriyle başlayan şedit bir manzumesi bulunmaktadır.
} 
1933-1940 yılları arasında etkin olan hareket son derece sınırlı bir etki alanına sahip olmuştur. İlk örgütlenme dönemlerinde Kürt Dağı'ndaki ağalarla karş1 karşıya gelen ve onlara karşı mücadele eden müritler daha sonra Fransızlara karşı mücadele etmeye başlamışlardır. Müritler bu mücadele de hem Suriye'deki Vatan Kitlesi'nden hem de Türkiye'den destek görmüşlerdir. İskenderun Sancağı'nın ilhakı için çabaladığ 1 1936-1938 yıllarında Türkiye'nin müritlere olan desteği zirve noktasına ulaşmıştır. Bir astsubay olan Bekir Fehmi gibi isimlerin varlığ dikkate alındığında Türkiye'nin harekete sadece lojistik destek vermekle kalmadığı, özellikle ağalar ve onları destekleyen Fransızlara karşı mücadeleye giriştikleri dönemde hareketin örgütlemesine de bizzat katkıda bulunduğu görülmektedir.

Halil İbrahim Soğukoğlu dahil hareketin Hanif Arabo, Bekir Fehmi, Ali Galip gibi tüm diğer önde gelen isimlerinin bir cinayet sonucu hayatlarını kaybetmeleri de incelemeye değer bir durumdur. Söz konusu kişiliklerin faaliyetlerine ve ölümlerine ilişkin verilere ulaşılması hareketin politik ve istihbari bağlantılarını biraz daha açıklığa kavuşturacaktır. Bununla birlikte hareketin organik bir boyutunun olduğu da görmezden gelinemez. Soğukoğlu'nun Kürtçe öğrenmesi, bölgeden evlilikler yapması, özellikle fakir kesimlerin bir kısım sosyal taleplerini icrası, tarikat ilişkileri vb. yerel halk ile kurduğu güçlü ilişkileri daha sonra da devam ettirmeye çalışması, Manisa'da iken de Kürt Dağı'nda olduğu gibi bir kısım yerel güç odakları ile karşı karşıya gelmesi gibi hususlar hareketin potansiyelinin salt resmiliğe de indirgenemeyeceğini göstermektedir.

Yine Kürt Dağı'ndaki Mürit Hareketi'nin Hatay'ın Türkiye'ye katılmasına için çaba harcandığı bir dönemde Türkiye'nin elini güçlendirdiği açıktır. Fakat daha önemlisi Türkiye, Kürt Dağı bölgesinin Türkiye’ye katılmasını da amaçlamış fakat reel politik gerekçelerle bundan vazgeçilmiş ve Hatay'ın ilhakı ile yetinilmiştir. Fakat söz konusu amaç resmi anlatıda kendisine yer bulmamıştır. Sadece Hatay'ın Türkiye'ye katılımını temin etmek amacıyla (daha fazlasını talep edip bir kısmına razı etme) Fransızlara karşı koz olarak kullanıldığı düşünülse dahi müritlerin bölgedeki silahlı faaliyetleri ve Türkiye'nin desteği dikkate alındığında resmi tarih yazımında sıklıkla vurgulandığı gibi Hatay'ın Türkiye'ye katılımının salt diplomatik faaliyetlerin neticesinde başarıldığ tarih kabulünün de sorgulanmasını gerektirir. Diplomatik çabaların başka araçlarla da desteklendiği görülmektedir.

Mürit Hareketi yakın tarihin büyük ölçüde görmezden gelinen bu sebeple de tarihçilerin dahi bilincinden uzak kalmış bir tarihi hadisedir. Hareket gerçekte modern/seküler ulus inşasını hedeflemiş yeni cumhuriyetin ve bu amaca adanmış tarih söyleminin üstesinden gelmek istediği (İslam, Nakşibendi, tarikat, şeyh, Kürt vb.) birçok unsuru bir araya getirmiştir. Hareket, dini bir kişiliğin (şeyh) etrafında çoğunluk Kürtlerle meskun ve Kürt adını taşıyan bir bölgede ortaya çıkmış dini karakteri olan (tarikat) bir harekettir. Dinsel karakterli yapılanmalar, dini sifatlar ve farklı kimliklere ait görünümler ise daima resmi söylemin dışına itilmiş, baskılanmış ve aşılmaya çalışılmışlardır. Oysa Mürit Hareketi söz konusu söyleme uymak bir yana onda gedikler açan rafine bir politik pragmatizm örneğidir. Politik amaçlarla içeride bastırılan şey sınırların dışında desteklenmiş, dinin politik potansiyelinden istifade edilmeye çalışılmıştır.

\section{KAYNAKÇA}


ABDO, D. Muhammed, "El Hayat'ül Siyasiye fi Cebeli l-Ekrad fi Kuruni l-Aşrin”" (Yirminci Yüzyılda Kürd Dağı’nda Siyasi Hayat), 2007.

http://www.syriakurds.com/2007/derasat/der012.htm (25.8.2014).

Başbakanlık Cumhuriyet Arşivi (BCA), Kararname, 3.2.1937, 5986

Kararname, 9.11. 1939, 12304

Kararname, Haziran 1941, 16033

Kararname, 19.7. 1934, 1058

BOIS, Th; V.F. Minorsky; D.N. MacKenzie. Kürtler ve Kürdistan. Çev. Kamuran Firatlı, İstanbul: Doz Basim Yayın, 2004.

ÇELEBIOĞLU, Şükrü. Mülakat, 2. 2. 2016, Gaziantep.

DEMIR, Yaşar. "Hatay'da Siyasi Çekişmeler ve Türkiye'nin Politikası (19361938)" History Studies, International Journal of History, Prof. Dr. Enver Konukçu Armağan1, 2012, s. 47-72.

DUMAN, Çiğdem. (2 Eylül 1938-29 Haziran 1939). Yayınlanmamış Yüksek Lisans Tezi, Mersin Üniversitesi Sosyal Bilimler Enstitüsü Tarih Anabilim Dalı. 2008

ERDOĞAN, Kenan; Aydoğan, Tuğba. "Manisa'da Medfun Mutasavvıf Bir Şair: Seyyid İbrahim Halil Efendi ve Divanı Kenz-i Şumus”, Celal Bayar Üniversitesi Sosyal Bilimler Dergisi, Cilt: 11, S. 3, 2013.

FUCCARO, Nelida. "Minorities and Ethnic Mobilisation: The Kurds in Northern Iraq and Syria", In: Meouchy, N. and Sluggett, P., (eds.), The British and French Mandates in Comparative Perspectives. Brill, 2004, s.579-595.

FUCCARO, Nelida. 'Manda Yönetimi Suriye'sinde Kürtler ve Kürt Milliyetçiliği: Siyaset, Kültür ve Kimlik', Kürt Milliyetçiliğinin Kökenleri, Abbas Vali (der.) içinde, çev. F. Adsay, Ü. Aydoğmuş, S. Kılıç, İstanbul: Avesta Yayınları, 2005

HOURANI, A. H. Syria and Lebanon, Beirut: Oxford University Press, 1968.

İNAN, Arı. Tarihe Tanıklık Edenler, Çağdaş Yayınları, İstanbul, 1997.

KONURALP, A. Nuri. Hatay'ın Kurtuluş ve Kurtuluşu Mücadelesi Tarihi, İskenderun: Hatay Postası Gazetesi Basımevi, 1973.

LANGE, Katharina. "Peripheral Experiences: Everyday Life in Kurd Dagh (Northern Syria) during the Allied Occupation in the Second World War", The World in World Wars. Experiences, Perceptions and Perspectives from Africa and Asia, içinde Ed. by Heike Liebau, Katrin Bromber, Katharina Lange, Dyala Hamzah and Ravi Ahuja. Brill, Leiden, 2010, s. 401-428.

LESCOT, Roger. Çiyayê Kurmênc $\hat{u}$ Tevgera Murûdan, wergerandin $\hat{\mathrm{u}}$ perawêznivîsîna Amed; lênêrîna Zînê, Weşanên Komela Jinên Kurdistanê li Swêdê, Stockholm, Sweden, 1993.

MARTIN, Thomas. The French Empire Between the Wars, Manchester: Manchester University Press, 2005.

MELEK, Abdurrahman. Hatay Nasıl Kurtuldu?, Ankara, Türk Tarih Kurumu Yayınları, 1991. 
ÖZTÜRK, Mustafa. “İzziye Kazasının Kuruluşu ve Milli Mücadeledeki Yeri”, Ankara Üniversitesi Tarih Araştırmaları Dergisi (Prof. Dr. Yücel Özkaya'ya Armağan), Ankara, 2005, s. 29-45.

ÖZTÜRK, Mustafa. 1938 Suriye Olaylarl ve İbrahim Halil Efendi'nin Faaliyetleri, Ankara, Türk Tarih Kurumu Yayınları, 1995.

PAYASLI, Volkan. "Halkevlerinin Hatay'daki Faaliyetleri ve Hatay'ın Türkiye'ye Katılım Süreci Üzerindeki Rolü Üzerine Bir Değerlendirme (19371939)". History Studies, C.3, S. 1, 2011.

PEHLIVANLI, Hamit. "İkinci Dünya Savaşı Öncesi Milli Emniyet Hizmetleri Teşkilatı İstihbarat Raporlarında Hatay”, 6. Askeri tarih semineri bildirileri, cilt:2, İstanbul, 1997, Genelkurmay Basımevi, 1999, s. 155.

SOĞUKOĞLU, Muhittin. "Şeyh İbrahim Halil'in Hayatı" Hulasatül-Adab $f$ Reddis-Serab içinde, İstikamet Yayınları, İstanbul, 1987.

SOĞUKOĞLU, Fehmi. Ibrahim Halil Efendi'nin Hayatı ve Itikadi Görüşleri, Yayınlanmamış Yüksek Lisans Tezi, Sakarya Üniversitesi, 2011.

SOĞUKOĞLU, Fehmi. “İbrahim Halil Efendi’nin Gaziantep/İslahiye'deki Dini Hayata Katkısı", Gaziantep'te Dini Hayat, içinde, Gaziantep Büyükşehir Belediyesi Kültür Yayınları, Gaziantep, 2017, s. 893-906.

SOĞUKOĞLU, Fehmi "İbrahim Halil Efendi ve Mürit Hareketi'nin Millî Mücadele'ye Katkısı", Millî Mücadele'de Güney Bölgesi Sempozyumu” içinde, Atatürk Araştırma Merkezi Yayınları. Ankara, 2015, s. 237-265.

TEJEL, Jordi. Syria's Kurds: History, Politics and Society, Routledge, 2009.

TOPAL, Coşkun. "Sancak (Hatay) Sorunu ve İkinci Dünya Savaşı Öncesi Süreçte Arap Kamuoyundaki Etkileri”, Trakya Üniversitesi Sosyal Bilimler Dergisi, 2009, C. 11, sy. 2, s.1- 16.

YORULMAZ, Şerife. "Fransız Manda Yönetimi Döneminde İskenderun Sancağ1 (Hatay)'nın Sosyo-Ekonomik ve Siyasal Durumuna İlişkin Bazı Kayıtlar (19181939)", Atatürk Yolu, cilt 6, say1 22 Kasım 1998, s. 231-259. 